\section{REVISTA}

MEXICANA DE

ECONOMÍA Y

FINANZAS

REMEF

THE MEXICAN JOURNAL OF

ECONOMICS AND FINANCE
Revista Mexicana de Economía y Finanzas, Nueva Época

Volumen 17 Número 1, Enero - Marzo 2022, pp. 1-13, e550

DOI: https://doi.org/10.21919/remef.v17i1.550

(Received: September 7, 2020, Accepted: February 9, 2021. Published: September 27, 2021)

\title{
The Relationship Between Share Prices and DUPONT Model Components: Evidence from Mexican Stock Market
}

\author{
Luis Manuel Tovar Rocha ${ }^{1}$ - Universidad Anáhuac México Norte, México \\ Julio Téllez Pérez - Universidad Anáhuac México Norte, México \\ Gabriel Alberto Agudelo Torres - Instituto Tecnológico Metropolitano Medellín, Colombia
}

This article presents the possible association between the three components (profit generation, asset efficiency and financial leverage) of the DUPONT ratio and share prices. The generalized method of moments (GMM) estimation was used with a sample of 23 companies traded on the Mexican stock exchange between 2008 and 2016, considering a period of three days before and three days after the presentation of the quarterly results. It is noted that the generation of profit and efficiency are the components of the DUPONT model that are strongly associated with stock prices, while the leverage effect is the component with the least impact. This empirical work is intended to help understand the relationship between accounting information and stock prices. The study identifies variables that influence decision-making and does not seek to be a predictive model of the value of actions in the future. This research differs from previous studies because it considers the volatility index (VIMEX) as a control variable.

JEL Classification: C23, D53, E32, E44, G12.

Keywords: Valuation, financial analysis, multiples, financial ratios, volatility.

\section{La relación entre los precios de las acciones y los componentes del modelo DUPONT: evidencia del mercado de valores mexicano}

En este artículo se presenta la posible asociación entre los tres componentes (generación de beneficios, eficiencia de activos y apalancamiento financiero) de la razón DUPONT y los precios de las acciones. Se utilizó la estimación del Método Generalizado de Momentos (GMM) con una muestra de 23 empresas cotizadas en la Bolsa Mxicana entre 2008 y 2016, considerando un período de tres días antes y tres días después de la presentación de los resultados trimestrales. Se observa que la generación de beneficios y eficiencia son los componentes del modelo DUPONT que están fuertemente asociados con los precios de las acciones, mientras que el efecto de apalancamiento es el componente con menor impacto. Este trabajo empírico pretende ayudar a comprender la relación entre la información contable y los precios de las acciones. El estudio identifica variables que influyen en la toma de decisiones y no busca ser un modelo predictivo del valor de las acciones en el futuro. Esta investigación difiere de estudios anteriores porque considera el índice de volatilidad (VIMEX) como una variable de control.

Clasificación JEL: C23, D53, E32, E44, G12.

Palabras clave: valoración, análisis financiero, múltiplos, razones financieros, volatilidad.

\footnotetext{
${ }^{1}$ Corresponding author. Email: luismanuel.tovar@anahuac.mx
}

* No source of funding for research development 


\section{Introduction}

The analysis of the return on equity (ROE) is important for shareholders as it allows them to know if the capital invested generates economic benefits. The ROE is calculated by dividing the net profit by stockholders' equity and the result indicates the profit of the shareholders for each monetary unit invested in the company. The ROE's behavior is based on three key concepts: the ability to generate profits, the efficiency of companies in managing their total assets and the financial leverage effect. These concepts are analyzed together in the model known as DUPONT. The use of ratio has been used over time to measure the profitability of companies, the efficiency of the board of directors and as a relative measure to compare companies through industries, among other things (Jin 2017). The purpose of this investigation is to find a link between the reporting information and the stock market which explains the behavior of price shares during the quarterly results publication period. Trejo, Noguera and White (2015) found that the most used financial ratios by analysts to formulate their investment recommendations in Mexico are the return on capital (ROE) and the return on investments (ROI). The importance of both financial ratios is that they provide information that analysts use to form their investment positions expressed through their buy-sell recommendations (Bradshaw 2002). The ROE is expressed as a percentage and can be calculated for any company if the shareholders' net profit are positive, otherwise it is generally not calculated. Situations as accumulated losses from previous years, high loans or an aggressive share repurchase program may cause the result to be negative. In all cases, a negative or extremely high ROE must be analyzed in detail.

In line with the DUPONT ratio, ROE depends on the generation of profits measured through the net margin, the effectiveness measured by the rotation of the assets, and the financial leverage obtained from the division between total assets and stockholders' equity. By interpreting these results, it is possible to generate a complete perspective of how companies create value for their shareholders (Téllez 2019).

In view of the importance of the analysis of profitability by investors or financial analysts, the ROE is considered to be the measure par excellence of the profitability obtained during a certain period; however, when it is used as an assumption for financial projections, it does not contain information relevant to the forecasts to be made (Penman 1991). To do this, it is necessary to be correlated with price to book value ratio (P/B) to incorporate information for forecasting profits (Ou and Penman 1989).

This research differs from previous studies because it considers the volatility index (VIMEX) as a control variable, which represents the 90-day market outlook for the Mexican Stock Exchange (BMV), providing a measure of market risk and investors' sentiments reference and what buyers and sellers expect to happen. Unfortunately, the VIMEX was published until august 2017 due to the lack of transactions of the derivatives market and there is no other indicator can replace it that fulfills the purpose of this research, for this reason the analysis period ends in 2016.

The generalized method of moment (GMM) was used to estimate the price of the share and the DUPONT components by considering a period of three days before and three days after the presentation of the quarterly results of the 23 main companies listed on the Mexican stock exchange 
from 2008 to 2016 (9 years). This set of companies represents more than 80 per cent of BMV's market capitalization and offers consistency in its financial indicators during the analysis period, in the same way, banking, real estate and insurance institutions are not included due to the parameters of analysis vis-à-vis companies in general. The evidence found indicates that profit generation and effectiveness are the components that present the greatest casual relation with the share prices three days before companies report profits, while financial leverage is the component with the lowest causal relationship of the three. The level of significance of the net margin and efficiency measured through the rotation of assets decreases significantly in the days following disclosure of accounting information. One possible explanation is that sales, net income, and total assets are the elements, due to their accounting nature, contain relevant information that contribute significantly to the formation of investors' expectations about the future of the company. Another possible explanation is analysts interpret the impact of the financial leverage effect on businesses by calculating other types of financial ratios, such as the total debt divided by stockholders' equity (D/E), the sum of both items results in the company's capital structure.

It should be noted that the study of the value relevance of accounting information in the Mexican stock market is practically non-existent, so this article contributes to the understanding of the functioning of capital markets in relation to the impact of information issued by listed companies in their financial statements.

The results of this empirical analysis may be of interest to the academy, companies and financial analysts, knowing that the ability to generate profits and the proper use of assets have a significant impact on the behavior of equity prices compared to the financial leverage. This evidence helps researchers and financial analysts to understand how the capital market assign prices to the book values of the companies and apply the appropriate financial ratio when they are evaluating companies.

The structure of the research work begins with the introduction, where the subject of the return of capital is presented conceptually, then a revision of the main empirical studies that have been carried out in this regard, to continue the description of the methodology used to determine the degree of association between the dependent variable and the independent variables selected in the hypothesis, and finally, the analysis of the results obtained by comparing them with previous researches.

\section{Literature Review}

Ball and Brown (1968) laid the foundations for the study of the relationship between stock prices and accounting information. The authors demonstrate that the traditional accounting has relevant information that impacts stock prices. The results obtained by these authors have led other researchers to study the relationship between prices and accounting information by highlighting studies carried out by Penman (1991) which conclude that ROE is not relevant as a risk measurement, but it can explain profitability based on its components (DUPONT). Additionally, the author comments the ROE contains information for forecasting profits based on shareholders' equity historical evolution. Ohlson (1995) and Feltham and Ohlson (1995) have established the modern basis for studying the relevance of the value of accounting information and its relationship with the market value of businesses through a financial model known as Residual Income (RI). This financial 
model links share prices to expected profits, returns and changes in the shareholders' book value. This model is based on three fundamental concepts: (a) the value of the company is the result of discounting expected dividends with a hurdle rate that reflects the risk of the investment, (b) the idea of clean surplus, which establishes that changes in the book value of stockholders' equity are equal to the profits of the period less dividends, leaving out transactions such as share repurchases and/or capital increases-decreases, (c) the latter concept refers to the fact that the contemporary residual benefit depends on the residual benefit of the previous period, on the understanding that the residual profit is the net profit generated in excess when the required minimum rate of return is reached. Durán, Lorenzo and Valencia (2007) applied the Ohlson model to a group of Mexican stock in the period 1991-2003, noting a significant value relevance of the stockholders' equity and net income with respect to share prices. This indicates that the components of the DUPONT model should be relevant when explaining the evolution of stock prices in the Mexican market.

With respect to the study of the value relevance of net income and stockholders' equity to explain the behavior of the shares, Easton and Harris (1991) found evidence suggesting that contemporary earnings expressed in levels and by variation has a significant relationship with the returns of the shares in a cross-sectional perspective rather than the analysis of the individual time series. Penman (1991) examines the return on capital in two dimensions, the first is ROE's ability to measure the relation between return and risk, and second is the information could provide to make financial projections. The author concluded ROE does not measure risk but provides information that helps forecast profits. Shroff (1995) concludes that contemporary profits have a high explanatory power to calculate the profitability of companies if they are somehow related to future profit expectations. The author also mentions that a high Price to Earnings ratio (PE) combined with a high ROE, contains information to estimate future profit growth. Fairfield and Yohn (2001) concluded that the typical breakdown of return on assets (ROA) in its two components, the net margin and asset rotation, does not provide sufficient elements for the preparation of financial projections, however, if consider the variation of return on assets $(\Delta \% \mathrm{ROA})$ and likewise its two components, provide relevant information to forecast the return on assets for the following year. Davis-Friday and Gordon (2005) examined the relevance of stockholders' equity value, net income, and cash flows during the 1994 financial crisis in Mexico, concluding that the relevance of shareholders' equity information content did not change significantly during the crisis period; on the contrary, it has increased its explanatory power over net profits. The explanatory power of net profits is affected by net losses. Soliman (2008) explores how financial analysts and investors make financial decisions based on the DUPONT components. The researcher noted that the change in asset turnover is highly related to future changes in efficiency and profit generation, compared with financial leverage. Also, the author mentions that market participants do not properly evaluate all the information contained in the return on capital, because in comparing analysts' projections with those elaborated under the DUPONT criterion and those made by others procedures, present significant bias. Botika (2012) analyses the impact of DUPONT ratio on the abnormal returns of companies on the Romanian capital market (2007-2010), noting for 2007, the market has given importance to profit generation and turnover. In 2008, the financial leverage is the only significant variable that explains the ROE's behavior, then in 2009 the three elements show a significant ratio to the company's returns. For 2010 
the profit generation stands out as the relevant variable. This indicates that the importance of the value of DUPONT components depends on the current economic situation. Bauman (2013) explores the relationship between the return on net operating assets (RNOA) with the net margin finding that the direction (positive/negative) that takes the change in net margin significantly affects future changes in RNOA. Kharatyan et al. (2017) analyzed the possible effect of DUPONT components on the NASDAQ 100 and found that the natural logarithm transformation of each component has a greater correlation with ROE compared to its original format. The turnover of assets is the variable with the highest coefficient followed by net margin and leverage, indicating that in the period analyzed (2015) the investors focused more on productivity than profits or debt level.

\section{Methodology}

To find the causal relationship between the study variables, the ordinary least squares (OLS) method is used as follows:

$$
P_{t}=\propto+b x_{t}+\mu_{t}
$$

Where $t=1, \ldots T$, considering $t$ as time dimension, $P_{t}$ the share price, $\propto$ and $b x$ are the vectors of the coefficients (slopes) and $\mu$ the random errors. If it is considered that the share price movement $\left(\mathrm{P}_{\mathrm{t}}\right)$ can be modelled through unexpected financial reporting information through bx modelling as follows:

$$
b x_{t}=\left[X_{t}-E\left(X_{t}\right)\right]
$$

Where $\mathrm{X}$ is the historical value of the ratio and $\mathrm{E}(\mathrm{X})$ is its expected future value. The difference between the two terms represents the unexpected information contained in each of the components of the DUPONT ratio. Replacing (2) in (1), it gets the following formula:

$$
P_{t}=\propto+b\left[X_{t}-E\left(X_{t}\right)\right]+\mu_{t}
$$

Therefore, the price of shares is only affected by unexpected information that is not directly observed. To avoid the disadvantages caused by possible structural changes over time, Biddle et al. (1995) suggest should only considered a single delay period in $\mathrm{E}\left(\mathrm{X}_{\mathrm{t}}\right)$, thus modifying formula (3), it is obtained:

$$
P_{t}=\propto+b_{1}\left(X_{t}\right)+b_{2}\left(X_{t-1}\right)+\mu_{t}
$$

If a second or third independent variable is added to equation (4), with its respective delay, two econometric problems may arise. The first one is a possible two-way relationship between explanatory variables that generate an endogeneity problem (Baltagi 2005), and the second problem arises from the invariant characteristics over time (fixed effects) per unit found in random errors $\left(\mu_{t}\right)$ that could be related to the independent variables. To deal with both problems, a dynamic panel model was constructed whose parameters are estimated using the generalized method of moments 
(GMM), using instrumental variables based on the differences and levels of the regressors (Arellano and Bond 1995, Blundell and Bond 1998) and proxy variables:

$$
P n_{i t}=\propto_{i t}+P n_{i, t-1}+\sum_{k=1}^{k} b_{k} X n_{k i t}+\sum_{k=1}^{k} b_{k} X n_{k i, t-1}+\varepsilon_{t}
$$

where $\mathrm{i}=1, \ldots \mathrm{N}, \mathrm{t}=1, \ldots \mathrm{T}$ and $\mathrm{k}=1, \ldots \mathrm{K}$ considering $\mathrm{i}$ as the unit of study (cross section), $\mathrm{t}$ as the time dimension and $\mathrm{k}$ the independent variables. In addition, $\mathrm{Pn}_{\mathrm{it}}$ represents the prices of contemporary shares, $\mathrm{Pn}_{\mathrm{i}, \mathrm{t}-1}$ as the lagged share prices and $\varepsilon$ the specific errors. In order to obtain more efficient estimators, the heteroscedastic weight matrix (Roodman 2009) is used compared to those obtained using a homoscedastic weights matrix (one step) and using the Hansen test (1982) to identify possible overidentification problems of the instrument. ${ }^{2}$

In addition to the analysis of incremental association degree that independent variables may have with the dependent variable, a hypothesis test was performed using statistics $\mathrm{F}$ as follows:

$$
\begin{aligned}
& H_{0}: b_{1}\left(X_{t}\right)=b_{2}\left(X_{t-1}\right)=0 \\
& H_{A}: b_{1}\left(X_{t}\right)=b_{2}\left(X_{t-1}\right) \neq 0
\end{aligned}
$$

To avoid possible problems of multicollinearity and scale, the variables were standardized by the following transformation:

$$
Z=\left(X_{i}-\bar{X}_{i}\right) / \sigma_{i}
$$

considering $\mathrm{Z}$ as the standardized variable with zero mean and standard deviation of one, $\mathrm{X}_{\mathrm{i}}$ is the variable of study in a moment $\mathrm{i}, \overline{\mathrm{X}}$ is the average of $\mathrm{X}_{\mathrm{i}}$ within a given period and $\sigma$ is the standard deviation of $\mathrm{X}_{\mathrm{i}}$.

\section{Variables}

As a dependent variable the closing price of the shares was considered $\left(\mathrm{Pn}_{\mathrm{it}}\right)$, which represents the price at which the trading of a financial asset ends on a specific day of trading on the capital markets. As independent variables, the three components of the DUPONT are taken into account, the net margin $(\mathrm{UNn} / \mathrm{VTn})_{\text {it }}$ obtained from dividing the net profit and sales of the last 12 months, the turnover of assets (VTn/ATn) it calculated using the sales of the last 12 months by dividing with the total assets, and financial leverage $(\mathrm{ATn} / \mathrm{Cn})_{\mathrm{it}}$ estimated as the division of total assets and stockholders' equity of a given period, in this case quarterly.

2 Overidentification means that the number of moment restrictions exceeds the number of interest parameters. The instruments can overfit endogenous variables, failing to expunge their endogenous components and biasing coefficient estimates. 
As a control variable, the Mexican volatility index (VIMEX) is used because all units (n) are exposed to the volatility of the Mexican economy (market risks). Also considered to be an exogenous variable because it's not affected by the estimates.

With the addition of the standardized variables from equation (7), the main equation is established to study the possible causal relationship between the variables proposed in this research work:

$$
\begin{aligned}
& Z P n_{i t}=b_{0}+Z P n_{i, t-1}+b_{1} Z(U N n / V T n)_{i t}+b_{2} Z(U N n / V T n)_{i, t-1}+b_{3} Z(V T n / A T n)_{i t}+ \\
& b_{4} Z(V T n / A T n)_{i, t-1}+b_{5} Z(A T n / C n)_{i t}+b_{6} Z(A T n / C n)_{i, t-1}+b_{7} \text { Vimex }+\varepsilon_{t}
\end{aligned}
$$

By estimating the equation (8), it is intended to determine the level of information provided by each of the three components of the DUPONT and how it affects the behavior of stock prices by analyzing the significance of the slope of the coefficient of the three variables, in contrast to the following hypothesis:

$H_{o:}$ Which of the three components of the DUPONT model has a strong explanatory relationship (relevance of value) with share prices.

\section{Sample Description}

A sample was formed with $23(\mathrm{n}=23)$ Mexican Stock Exchange (BMV), companies public-trade during the period 2008-2016, that met the following filters: 1) showing complete financial information ( $\mathrm{t}=32$ quarters), and 2) non-financial corporations (excluding banks, real estate and insurance companies). The financial information for the estimates was obtained from the Economatica database. Table 1 shows the statistical description of the variables sticking out the UN/VT ratio, showing an average of 13.25 per cent and a coefficient of variation of 0.90 , being the component of the DUPONT with the greatest variation in the period analyzed and heterogeneity compared to asset rotation and financial leverage. The average of the VT/AT ratio is 0.77 meaning for each monetary unit invested in total assets, 0.77 is generated in proportion to sales. The financial leverage effect is the component that shows the lowest coefficient of variation since the corporate capital structure does not presents significant changes over time when companies operate at their current capacity. The capital structure changed when companies enter a phase of expansion mainly financed by debt (Caskey, Hughes and Liu 2012). For VIMEX, the greater the index, the greater the volatility. This variation reflects the economic situation (favorable/adverse) over a period of time. In 2008, the mortgage crisis in the United States of America led to the index reaching 38.1 points, reflecting the impact of that event on Mexican financial markets. Subsequently, VIMEX decreased in the following years to an average volatility of 14.48 points in 2016, representing a significant drop of $62 \%$. 
Table 1. Resume (2008 - 2016)

\begin{tabular}{|c|c|c|c|c|c|}
\hline Variables & Average & $\begin{array}{c}\text { Standard } \\
\text { deviation }\end{array}$ & Min & Max & $\begin{array}{c}\text { Coefficient } \\
\text { of variation }\end{array}$ \\
\hline$R O E^{*}$ & $15.6 \%$ & $17.9 \%$ & $-135.5 \%$ & $147.2 \%$ & 1.15 \\
\hline$U N / V T^{*}$ & $13.25 \%$ & $11.97 \%$ & $-33.6 \%$ & $48.9 \%$ & 0.90 \\
\hline$V T / A T^{*}$ & $0.773 \mathrm{x}$ & $0.433 \mathrm{x}$ & $0.115 \mathrm{x}$ & $3.701 \mathrm{x}$ & 0.56 \\
\hline$A T / C C^{*}$ & $2.283 \mathrm{x}$ & $1.191 \mathrm{x}$ & $1.050 \mathrm{x}$ & $12.60 \mathrm{x}$ & 0.52 \\
\hline$V I M E X^{\times}$ & $21.52 \mathrm{x}$ & $10.01 \mathrm{x}$ & $10.14 \mathrm{x}$ & $67.82 \mathrm{x}$ & 0.46 \\
\hline
\end{tabular}

*Values without transformation and estimates were made on a quarterly basis with information from the last 12 months in the case of the income statement data.

${ }^{\times}$Used daily variation for calculations

Source: Researcher estimations / Stata v.14

Table 2 shows Pearson's correlation matrix where financial leverage is the variable with the highest linear relationship to share prices registering a positive correlation coefficient of 0.1727 , following the net margin with a coefficient of 0.1014 , both significant at $1 \%$. The turnover of the assets has no relation to share prices as it has a non-significant probability. This could be explained in terms of what happened in 2008 as many Mexican companies showed high debt levels at the end of 2007, expecting 2008 to present the same features of economic growth as the previous years, however, the sudden fall in US markets, the debt became the central variable of analysis by market participants trying to determine the possible effect on profit generation, leaving in a second term the productivity of assets. To have a business strategy whose purpose is to streamline asset management, it is necessary the economy shows signs of long-term stability, otherwise, with a weak economy and uncertain in the short term, business survival will only be marked by the generation of profits. As for VIMEX, there is a negative correlation of 0.513 which indicates an inverse relationship with price fluctuations, interpreting that a high indicator value, the probability of a fall in the stock market, increases.

Table 2. Pearson's Correlation matrix (2008 - 2016)

\begin{tabular}{|c|c|c|c|c|c|}
\hline & $\boldsymbol{P}$ & UN/VTA & VTA/AT & AT/CC & Vimex \\
\hline UN/VTA & 1 & & & & \\
\hline VTA/AT & $\begin{array}{c}.1014 \\
(.006)^{* * *}\end{array}$ & 1 & & & \\
\hline AT/CC & $\begin{array}{c}.0278 \\
(0.452)\end{array}$ & $\begin{array}{c}.2804 \\
(0.000)^{* * *}\end{array}$ & 1 & & \\
\hline Vimex & $\begin{array}{c}.000)^{* * *} \\
(0.000)^{* * *}\end{array}$ & $\begin{array}{c}-.2929 \\
(0.000)^{* * *}\end{array}$ & $\begin{array}{c}-.2236 \\
(0.000)^{* * *}\end{array}$ & 1 & \\
\hline
\end{tabular}

*significant at $10 \%$; ${ }^{* *}$ significant at $5 \%$; ${ }^{* * *}$ significant at al $1 \%$

Source: Researcher estimations / Stata v.14 


\section{Empirical results}

As a first step, Fisher's unit-root test (Fisher 1932, Maddala and Wu 1999) was performed to find unit root problems where the null hypothesis is all panels content unit roots. The table 3 shows the results of the different statistical tests indicating that there is not enough evidence to accept the null hypothesis and it is concluded that the variables are stationary.

Table 3. Fisher Unit-Root test (2008 - 2016)

\begin{tabular}{|c|c|c|c|c|}
\hline & UN/VTA & VTA/AT & AT/CC & Vimex \\
\hline Inverse chi-squared & $0.0097^{* * *}$ & $0.016^{* *}$ & $0.000^{* * *}$ & $0.000^{* * *}$ \\
\hline Inverse normal & $0.0132^{* *}$ & $0.0303^{* *}$ & $0.000^{* * *}$ & $0.000^{* * *}$ \\
\hline Inverse logit & $0.0126^{* *}$ & $0.0214^{* *}$ & $0.000^{* * *}$ & $0.000^{* * *}$ \\
\hline Modified inv. Chi squared & $0.0041^{* * *}$ & $0.0067^{* * *}$ & $0.000^{* * *}$ & $0.000^{* * *}$ \\
\hline \multicolumn{4}{|c}{ *significant at 10\%; ${ }^{* *}$ significant at 5\%; *** significant at al 1\% } \\
Source: Stata v,14
\end{tabular}

Subsequently, the equation (8) was used to calculate the possible causal relationship between DUPONT components and the share prices for the period 2008-2016 (table 4). The results show (UN/VT) $)_{\text {nit }}$ and (UN/VT) nit-1 present the higher F statistic compared to that shown by asset turnover and financial leverage. This indicates that the net margin is the variable with the highest value relevance, which explains the changes in share prices three days before the presentation of the companies' quarterly financial reports, similar results obtained by Easton and Harris (1991), Dechow (1994) and Easton (1999). However, in the days following the company reported date, the relationship between the contemporary variable and the lagged variable decreases until the effect of the incremental information disappears completely on the third day. This can be explained from the point of view of the market and its perception of the ability of companies to generate profits, and how the effect (positive or negative) of the transitional elements that affect earnings fade as time passes (Beaver and Morse 1978). Another explanation may be that the expectations of the market of the forward earnings per share (EPS) are not satisfied, therefore the share price falls significantly. The importance of EPS by analysts is of such magnitude, that small variations in this multiple, significantly impacts the share prices. According to Trejo et al (2015), the EPS is the ratio most used by analysts of brokerage firms to make their investment decisions, inferring that the income statement, and everything that happened inside it, has more value relevance than balance sheet components.

It should also be noted that the delayed variables corresponding to the net margin and turnover of assets show negative signs, indicating an inverse relationship with the price of the shares, emphasizing that companies that present a low level of profit growth or efficiency over a year tend to record high multiples the following year (Molodovsky 1953). The transition from the delayed variable to the contemporary variable is based on the idea that the market has an opinion about the performance of the company and when that opinion changes, means the market's expectations about growth of profits and return of capital are adjusted with the new information provided by the financial reports of companies. The policy of paying dividends also has an important role too, because 
without it, the expected benefit would be limited only to the change in the price of shares, increasing their exposure to market risks due to the implementation of a strategy for the repurchase of shares replacing dividends (Fama and French 1992, 1995).

The variable that measures the financial leverage has no relation to the movements of stock prices days before and after the delivery of the financial information, perhaps due to VIMEX index and the delayed variables of the net margin and assets turnover already incorporate, in some way, the effects of market risk that affect the capital structure.

\section{Conclusions}

This study analyses the relationship between the components of the DUPONT ratio and the movements of share prices in the days preceding and following the date of the quarterly financial report. DUPONT is an analytical model widely used by financial analysts to understand the behavior of return of equity. The evidence suggests that profit generation is the most important variable that explains the movement of stock prices. Investors and financial analysts care more about the ability of companies to obtain gains every quarter than improvements in efficiency or a good management of financial leverage.

Considering financial analysts are the main users of information contained in the financial reports of the companies, it is possible to apply the results of this study to reduce the set of ratios, normally used, that allow the development of simple and straightforward financial models.

Asset efficiency is the main component that supports investment strategies in the long term. For this to work, its necessary to have the following elements: a better institutional ecosystem, strong legal frameworks, effective corporate governance practices, a solid economy, among others. However, the short and long-term weakness of the Mexican economy make companies implement short-term strategies to survive in the face of uncertainty, where profit generation is the priority.

We recognize as a limitation in our study the lack of comparison with the financial reports issued by analysts to verify the outcomes and the size of the sample. Despite the fact the Mexican capital market is small and poorly developed, the methodology used is robust and the results obtained have a strong statistical support. Therefore, the results are relevant and complement with new findings the knowledge of this line of research.

This empirical work aims to contribute to the understanding of the relationship between accounting information and stock prices, where research on this subject in Mexico is growing. As a possible future line of research, it is recommended to explore the relevance of the value of different financial ratios such as liquidity and solvency in relation to stock price behavior, use this methodology to study other markets in Latin America or countries with more developed capital markets such as the United States and Europe. 
Table 4. Generalized method of moments (GMM) 2008-2016

\begin{tabular}{|c|c|c|c|c|c|c|c|}
\hline Variable & $P_{t-3}$ & $P_{t-2}$ & $P_{t-1}$ & $P$ & $P_{t+1}$ & $\boldsymbol{P}_{t+2}$ & $P_{t+3}$ \\
\hline \multirow[t]{2}{*}{$U N / V t_{n i t}$} & $-0.09 *$ & $-0.08^{*}$ & $-0.11^{* *}$ & $-0.10 *$ & $-0.12 *$ & $-0.10^{*}$ & -0.08 \\
\hline & $(-1.89)$ & (1.67) & $(-2.23)$ & $(-1.93)$ & $(-1.78)$ & $(-1.92)$ & $(-0.88)$ \\
\hline \multirow[t]{2}{*}{$U N / V t_{\text {nit-1 }}$} & $0.09 *$ & $0.15^{* *}$ & $0.10^{*}$ & $0.12^{* *}$ & 0.06 & 0.09 & 0.14 \\
\hline & $(1.76)$ & $(2.32)$ & (1.84) & $(2.21)$ & $(1.02)$ & $(1.50)$ & $(1.52)$ \\
\hline \multirow[t]{2}{*}{$F^{a}$} & $11.97^{* * *}$ & $23.19^{* * *}$ & $11.81^{* * *}$ & $24.43^{* * *}$ & $14.97^{* * *}$ & $8.21^{* * *}$ & 2.22 \\
\hline & $(0.00)$ & $(0.00)$ & $(0.00)$ & $(0.00)$ & $(0.00)$ & $(0.00)$ & $(0.15)$ \\
\hline \multirow[t]{2}{*}{$V T / A T_{n i t}$} & $-0.13^{* * *}$ & $-0.16^{* * *}$ & $-0.22^{* *}$ & $-0.13^{*}$ & -0.14 & -0.11 & -0.22 \\
\hline & $(-2.96)$ & $(-2.95)$ & $(-1.93)$ & $(-1.76)$ & $(-1.39)$ & $(-1.41)$ & $(-1.73)$ \\
\hline \multirow[t]{2}{*}{$V T / A t_{n i t-1}$} & $0.10^{*}$ & 0.07 & 0.05 & 0.06 & 0.08 & 0.04 & $0.16^{* *}$ \\
\hline & $(1.67)$ & $(1.27)$ & $(0.67)$ & (1.39) & (1.07) & $(0.57)$ & $(2.44)$ \\
\hline \multirow[t]{2}{*}{$F^{a}$} & $5.57^{* *}$ & $8.86^{* *}$ & 2.21 & $6.76^{* *}$ & $6.97^{* *}$ & 1.39 & $5.80 * *$ \\
\hline & $(0.03)$ & $(0.03)$ & $(0.15)$ & $(0.02)$ & $(0.02)$ & $(0.25)$ & $(0.03)$ \\
\hline \multirow[t]{2}{*}{$A T / C_{n i t}$} & 0.10 & 0.07 & 0.01 & 0.06 & 0.08 & 0.08 & $0.15^{* *}$ \\
\hline & $(0.07)$ & $(1.30)$ & $(0.03)$ & $(1.47)$ & (1.18) & $(1.07)$ & $(2.11)$ \\
\hline \multirow[t]{2}{*}{$A T / C_{n i t-1}$} & 0.06 & $0.10^{*}$ & $0.11^{*}$ & $0.11^{*}$ & 0.04 & 0.02 & 0.14 \\
\hline & $(1.06)$ & (1.87) & $(2.38)$ & $(2.81)$ & $(0.68)$ & $(0.24)$ & $(1.66)$ \\
\hline \multirow[t]{2}{*}{$F^{a}$} & 1.25 & 0.28 & 1.30 & 0.63 & 0.46 & 0.34 & 0.01 \\
\hline & $(0.28)$ & $(0.60)$ & $(0.27)$ & $(0.44)$ & $(0.50)$ & $(0.57)$ & $(0.93)$ \\
\hline \multirow[t]{2}{*}{ VIMEX } & $0.22^{* * *}$ & $0.20^{* * *}$ & $0.18^{* * *}$ & $0.19^{* * *}$ & $0.21^{* * *}$ & $0.17^{* * *}$ & $0.17^{* * *}$ \\
\hline & (4.99) & $(4.76)$ & (5.31) & $(6.30)$ & (5.39) & $(8.10)$ & $(6.88)$ \\
\hline \multirow[t]{2}{*}{ Constant } & $-0.20^{* * *}$ & $-0.19 * * *$ & $-0.20^{* * *}$ & $-0.22^{* * *}$ & $-0.20 * * *$ & $-0.19^{* * *}$ & $-0.16^{* * *}$ \\
\hline & $(-8.65)$ & $(-8.52)$ & $(-11.23)$ & $(-11.83)$ & $(-8.74)$ & $(-6.51)$ & $(-5.36)$ \\
\hline$A R(1)$ & $0.00^{* * *}$ & $0.00^{* * *}$ & $0.08^{*}$ & $0.01^{* * *}$ & $0.00^{* * *}$ & $0.01^{* * *}$ & $0.00^{* * *}$ \\
\hline$A R(2)$ & 0.71 & 0.89 & 0.92 & 0.70 & 0.25 & 0.93 & 0.11 \\
\hline Hansen test ${ }^{b}$ & 0.70 & 0.88 & 0.83 & 0.89 & 0.59 & 0.81 & 0.37 \\
\hline Observations & 851 & 851 & 851 & 851 & 851 & 851 & 851 \\
\hline
\end{tabular}

${ }^{*}$ significant at $10 \% ;{ }^{* *}$ significant at $5 \% ;{ }^{* * *}$ significant at al $1 \%$

${ }^{a}$ The p-value in parentheses represents the statistical test of two queues of the null hypothesis of information content absent, $\mathrm{H}_{0}: \mathrm{b}_{1} \mathrm{Z}\left(\mathrm{X}_{\mathrm{t}}\right)=\mathrm{b}_{2} \mathrm{Z}\left(\mathrm{X}_{\mathrm{t}-1}\right)=0$.

${ }^{b}$ Statistical test of the null hypothesis of non-overidentification of the instruments (two-step). 


\section{References}

[1] Arellano, M. \& Bond, S.R. (1991). Some Tests of Specification for Panel Data: Monte Carlo Evidence and an Application to Employment Equations, Review of Economic Studies, 58, 277-297. https://doi.org/10.2307/2297968

[2] Ball, R. \& Brown P. (1968). An Empirical Evaluation of Accounting Income Numbers. Journal of Accounting Research, 6, 159-178. https://doi.org/10.2307/2490232

[3] Baltagi, H.B. (2005). Econometric Analysis of Panel Data (3rd ed.). New York: John Wiley \& Sons. https://doi.org/10.1017/s0266466600006150

[4] Basu, S. (1977). Investment Performance Of Common Stocks In Relation To Their Price-Earnings Ratios: A Test Of The Efficient Market Hypothesis. The Journal of Finance, 32(3), 663-682. https://doi.org/10.1111/j.1540-6261.1977.tb01979.x

[5] Bauman, M.P. (2014). Forecasting operating profitability with DUPONT analysis: Further evidence, Review of Accounting and Finance, 13(2), 191-205. https://doi.org/10.1108/RAF-11-2012-0115

[6] Beaver, W. \& Morse, D. (1978). What Determines Price-Earnings Ratios? Financial Analysts Journal, 6576. https://doi.org/10.2469/faj.v34.n4.65

[7] Biddle, G.C., Seow, G. S. \& Seigel, F. (1995), Relative versus Incremental Information Content. Contemporary Accounting Research, 12, 1-23. https://doi.org/10.1111/j.1911-3846.1995.tb00478.x

[8] Blundell, R. \& Bond, S. (1998). Initial conditions and moments restrictions in dynamic panel data models, Journal of Econometrics, 87, 115-143. https://doi.org/10.1016/s0304-4076(98)00009-8

[9] Botika, M. (2012), The use of DUPONT analysis in abnormal returns evaluation: Empirical study of Romanian market. Social and Behavioral Sciences. 62, 1179-1183. https://doi.org/10.1016/j.sbspro.2012.09.202

[10] Bradshaw, M. (2002). The use of target prices to justify sell-inside analysts' stock recommendations. Accounting Horizons, 16(1), 27-41. https://doi.org/10.2139/ssrn.303162

[11] Caskey, J., Hughes, J., \& Liu, J. (2012). Leverage, excess leverage, and future returns. Review of Accounting Studies, 17(2), 443-471. https://doi.org/10.1007/s11142-011-9176-1

[12] Collins, D.W., Maydew, E.L. \& Weiss, I.S. (1997). Changes in the value-relevance of earnings and book values over the past forty years. Journal of Accounting and Economics, 24(1), 39-67. https://doi.org/10.1016/s0165-4101(97)00015-3

[13] Davis-Friday, P. \& Gordon, E.A. (2005). Relative valuation roles of equity book value, net income, and cash flows during a macroeconomic shock: the case of Mexico and the 1994 currency crisis. Journal of International Accounting Research, 4(1), 1-21. https://doi.org/10.2308/jiar.2005.4.1.1

[14] Dechow, P.M. (1994). Accounting earnings and cash flows as measures of firm performance: The role of accounting accruals. Journal of Accounting and Economics, 18, 3 - 42 . https://doi.org/10.1016/0165-4101(94)90016-7

[15] Durán Vázquez, R., Lorenzo Valdéz, A., \& Valencia Herrera, Hbarton. (2009). Value Relevance of the Ohlson model with Mexican data. Contaduría y Administración, (223). https://doi.org/10.22201/fca.24488410e.2007.624

[16] Easton, P. D. (1999). Security Returns and the Value Relevance of Accounting Data. Accounting Horizons, 13(4), 399-412. https://doi.org/10.2308/acch.1999.13.4.399

[17] Easton, P. D., \& Harris, T. S. (1991). Earnings as an Explanatory Variable for Returns. Journal of Accounting Research, Spring, 19-36. https://doi.org/10.2307/2491026

[18] Fairfield, P.M. \& Yohn, L.T. (2001). Using Asset Turnover and Profit Margin to Forecast Changes in Profitability. Review of Accounting Studies. 6, 371-385. https://doi.org/10.1023/A:1012430513430 
[19] Fama, E.F. \& French, K.R. (1992). The Cross-Section of Expected Stock Returns. Journal of Finance,47(2), 427-465. https://doi.org/10.2307/2329112

[20] Fama, E.F. \& French, K.R. (1995). Size and Boot-to-Market in Earnings and Returns. Journal of Finance,50(1), 131-155. https://doi.org/10.1111/j.1540-6261.1995.tb05169.x

[21] Feltham, G. A., \& Ohlson, J. A. (1995). Valuation and Clean Surplus Accounting for Operating and Financial Activities. Contemporary Accounting Research, 11(2), 689-731. https://doi.org/10.1111/j.1911-3846.1995.tb00462.x

[22] Fisher, R.A. (1932). Statistical methods for research workers $\left(4^{\text {th }}\right.$ ed.). Oliver \& Boyd. https://doi.org/10.1007/978-1-4612-4380-9_6

[23] Hansen, L.P. (1982). Large Sample Properties of Generalized Method of Moments Estimators. Econometrica, 50(4), 1029-1059. https://doi.org/10.2307/1912775

[24] Jin, Y. (2017). DUPONT Analysis, Earnings Persistence, and Return on Equity: Evidence from Mandatory IFRS Adoption in Canada. Accounting Perspectives, 16(3), 205-235. https://doi.org/10.1111/1911-3838.12142

[25] Kharatyan, D., Lopes, J.C. \& Nunes, A. (2017). Determinants of Return on Equity: Evidence From NASDAQ 100. XXVII Jornadas Hispano-Lusas Gestión Científica. https://doi=10.1.1.610.5026\&rep=rep1\&type=pdf

[26] Maddala, G.S. \& Shaowen Wu (1999). A Comparative Study of Unit Root Test with Panel Data and a New Simple Test. Oxford Bulletin of Economics and Statistics. 61(S1), 631-652. https://doi.org/10.1111/1468-0084.0610s1631

[27] Molodovsky, N. (1953). A Theory of Price-Earnings Ratios. Financial Analysts Journal, November 1953, 65-80. https://doi.org/10.2469/faj.v9.n5.65

[28] Ohlson, J. A. (1995). Earnings, Book Values, and Dividends in Equity Valuation. Contemporary Accounting Research, 11(2). https://doi.org/10.1111/j.1911-3846.1995.tb00461.x

[29] Ou, J.A. \& Penman, S.H. (1989). Accounting Measurement, Price-Earnings Ratio, and the information Content of Security Prices. Journal of Accounting Research, 27,111-144. http://dx.doi.org/10.2307/2491068

[30] Penman, S. H. (1991). An Evaluation of Accounting Rate-of-return. Journal of Accounting, Auditing \& Finance, 80(2). https://doi.org/10.2308/accr.2005.80.2.501

[31] Roodman, D. (2009). How to do xtabond2: An Introduction to difference and system GMM in stata. The Stata Journal, 9(1), 86-136. https://doi.org/10.2139/ssrn.982943

[32] Shroff, P.K. (1995). Determinants of the Returns-Earnings Correlation. Contemporary Accounting Research, 11(1), 41-55. https://doi.org/10.1111/j.1911-3846.1995.tb00480.x

[33] Soliman, M.T. (2008) The Use of DUPONT Analysis by Market Participants. The Accounting Review. 83 (3), 823-853. https://doi.org/10.2308/accr.2008.83.3.823

[34] Téllez, J. (2019). La Eficiencia de los múltiplos de capital: Caso México 2008-2016, Contaduría y Administración, $\quad$ 64(4). http://dx.doi.org/10.22201/fca.24488410e.2018.1651 Trejo, C.O., Noguera, M. \& White, S. (2015). Financial ratios used by equity analyst's in Mexico and stock returns. Contaduría y Administración, 60, 578-592. https://doi.org/10.1016/j.cya.2015.02.001 